\title{
MINERAL NUTRIENT COMPOSITION OF LEAVES AND FRUITS OF BLACK TABLE OLIVE CV. GEMLIK
}

\author{
Haluk Bașar and Serhat Gürel ${ }^{*}$ \\ Uludağ University, Agricultural Faculty, Department of Soil Science and \\ Plant Nutrition, 16032 Nilüfer, Bursa, Turkey
}

Key words: Mineral nutrients, Leaves and fruits, Black table olive

\begin{abstract}
A comparative study on mineral composition of the olive trees was made to see the changes in the content of the nutrient elements in the component (leaf and fruit) parts. Differences between the leaf and fruit mean concentrations of the whole elements examined were found to be statistically significant. Potassium and boron concentrations in the fruits were higher than that of the leaves. But, the concentration of the rest of the elements in the fruits was lower than the leaves.

Due to the unique nutritional and gastronomic properties of olive (Oleaeuropaea L.) oil, world demand for it has increased dramatically in the last decade. This trend together with the introduction of intensive management practices, including irrigation has led to increase tree nutrient demands in olive orchards (Ziporiet et al. 2011). Mineral fertilization has been reported to influence olive yield and quality (Fernández-Escobar et al. 2006).

The Marmara region is the prime producer of table olives in Turkey. However, there are some problems with yield, quality and alternate bearing in the olive orchards. The study was conducted in 64 orchards with cv. Gemlik table olive trees in towns of İznik, Orhangazi, Gemlik, Mudanya and Nilüfer of Bursa province.

The leaf samples were collected, prepared and analyzed for the macro-and micronutrients contents as described by (Kacar and İnal 2008). All the analysis were carried out in duplicates and the results were statistically analyzed using $\mathrm{t}$-test.

Percentage of the leaves containing macro- and micronutrients below the normal levels were $39,6,100,11$ and 56 of samples for $\mathrm{N}, \mathrm{P}, \mathrm{K}, \mathrm{Ca}$ and $\mathrm{Mg}$, respectively and 13, 86, 31, 8 and 100 for $\mathrm{Fe}, \mathrm{Zn}, \mathrm{Mn}, \mathrm{Cu}$ and $\mathrm{B}$, respectively. As a result, no examined nutrients were found to be sufficient according to sufficiency ranges proposed by Jones et al. (1991).

Percentage of the fruits containing micro-nutrients below those normal values were 87 and 39 of fruit samples for $\mathrm{Fe}$ and $\mathrm{Zn}$, respectively (Table 1). The rest of the macro and micro-nutrients in the fruits were sufficiently higher than the normal values according to Güceyü and Başoğlu (2010)

The concentrations of all elements determined in the leaves were dramatically higher than that in the fruit except $\mathrm{K}$ and $\mathrm{B}$ (Table 1). These differences also proved to be statistically significant. Partitioning pattern of the elements in the component parts is very important for the diagnosing nutrient deficiency. Therefore, both fruit and leaf analysis should be individually proposed for evaluations of sufficiency status of $\mathrm{K}$ and $\mathrm{B}$ in the olive trees.
\end{abstract}

*Author for correspondence: <sgurel@uludag.edu.tr>. 
Table 1 . Concentrations of the elements in inorganic elements.

\begin{tabular}{llccccccccc}
\hline \multicolumn{10}{c}{} & \multicolumn{10}{c}{$\mathrm{mg} / \mathrm{kg}$} \\
\hline & $\mathrm{N}$ & \multicolumn{1}{c}{$\mathrm{P}$} & \multicolumn{1}{c}{$\mathrm{K}$} & $\mathrm{Ca}$ & $\mathrm{Mg}$ & $\mathrm{B}$ & $\mathrm{Fe}$ & $\mathrm{Zn}$ & $\mathrm{Cu}$ & $\mathrm{Mn}$ \\
\hline Leaf & $15200 \mathrm{a}$ & $1200 \mathrm{a}$ & $4300 \mathrm{~b}$ & $12300 \mathrm{a}$ & $1900 \mathrm{a}$ & $7.42 \mathrm{~b}$ & $118.67 \mathrm{a}$ & $12.56 \mathrm{a}$ & $32.42 \mathrm{a}$ & $32.67 \mathrm{a}$ \\
Fruit & $7000 \mathrm{~b}$ & $1100 \mathrm{~b}$ & $14000 \mathrm{a}$ & $700 \mathrm{~b}$ & $600 \mathrm{~b}$ & $15.76 \mathrm{a}$ & $10.84 \mathrm{~b}$ & $8.78 \mathrm{~b}$ & $10.54 \mathrm{~b}$ & $4.60 \mathrm{~b}$ \\
$\mathrm{t}$ ratio & 26.74 & 4.19 & -34.85 & 51.16 & 32.35 & -6.93 & 16.96 & 6.05 & 6.23 & 18.96 \\
Significance & $* *$ & $* *$ & $* *$ & $* *$ & $* *$ & $* *$ & $* *$ & $* *$ & $* *$ & $* *$ \\
\hline
\end{tabular}

The means are averages of 64 groves. $p>0,01 .{ }^{* *} p>0,05 .{ }^{*}$ n.s. not significant.

Leaf $\mathrm{K}$ concentrations regularly declines from the beginning of growing season and translocates to the fruits as the season progress. Therefore, $\mathrm{K}$ concentration sharply decreases in the leaves (Table 1) due to a large $\mathrm{K}$ accumulation in the fruits (Deidda 1968). Higher B concentrations in fruits than that of the leaves could be due to translocation of B from leaves to developing tissues (Delgado et al. 1994).

\section{Acknowledgements}

This work is a part of the research which was supported by the Research Fund of The University of Uludağ, Project number: Z-2008/14 awarded to Haluk Başar as principal investigator. The authors would like to thank to Marmarabirlik (The cooperative of olive producer farmers in the region) for support of transportation.

\section{References}

Deidda P 1968. Observation on the growth of olive fruits variations of some major elements in the leaves and fruits and accumulation of oil, Studi. Sassar, Ser. III. No. 16, pp. 501 - 513.

Delgado A, Benlloch M and Fernández-Escobar R 1994. Mobilization of boron in olive trees during flowering and fruit development. Hort. Sci. 29: 616-618.

Fernández-Escobar R, Beltrán G, Sánchez-Zamora MA, García-NoveloJ, Aguilera MP and Uceda M 2006. Olive quality decrease with nitrogen over fertilization. Hort. Sci. 41: 215 - 219.

Güceyü Ç and Başoğlu F 2010. The quality norms of cv Gemlik olives. In: TokuşoğluÖ (Ed), Olives, the special fruit. SidasPress. İzmir, Turkey. p. 124.

Jones JBJr, Wolf B and Mills HA 1991. Plant Analysis Handbook. Micro-Macro Publishing Inc., Athens, GA, USA. p. 51.

Kacar B and İnalA 2008. Plant Analysis. Nobel Press. No. 1241, pp. 115-120 (in Turkish).

Zipori I, Yermiyahu U, Ben-Gal A and Dag A 2011. Response of oil-olive trees to iron application. Proc. IS. In: Yermiyahu U et al. (Eds), Olive Irrigation and Oil Quality. Acta Hort. 888: 295 - 300. 